\section{Research Article}

(C) 2021 Okpa et al.. This is an open access article licensed under the Creative Commons Attribution-NonCommercial 4.o International License (https://creativecommons.org/licenses/by-nc/4.o/)

\title{
Child Labour and Delinquent Behaviour in Nigeria: A Risk Factor Analysis
}

\author{
John Thompson Okpa ${ }^{1 *}$ \\ Emmanuel Eshiotse ${ }^{1}$ \\ Nnana Okoi Ofem² \\ Akomaye Sylvester ${ }^{1}$ \\ Ubong Stephen Andrew3 \\ ${ }^{1}$ Sociology Department, University of Calabar, \\ Cross River State, Nigeria \\ ${ }^{2}$ Department of Social work, University of Calabar, \\ Cross River State, Nigeria \\ ${ }^{3}$ Criminology \& Security Studies Department, \\ Arthur Jarvis University, Akpabuyo, Cross River State, Nigeria \\ ${ }^{*}$ Corresponding Author
}

DOI: https://doi.org/10.36941/ajis-2021-0o67

\begin{abstract}
The thrust of this paper is to analyse the issues surrounding child labour and delinquent behaviour, linking the core of the problem to parents' financial status, cultural practices and parental literacy. The article presents that child labour is a widespread global abnormality, wherein underage children are illegally engaged in undignified, dangerous, and debasing economic activities without considering the implication on their safety, security and dreams. These children are unduly engaged or employed to work for longer hours; usually at dumpsites, industrial layouts, farmlands, and in other settings; as servants, labourers and scavengers. A situation that has a significant socio-psychological effect, which in extreme cases results in delinquent behaviour. Child labour invariably creates a feeling of false maturity syndrome, as well as, exposes children to negative habits in the course of interacting with people oflow-virtue, who often in the guise of patronizing their wares indoctrinate them into their unsavoury ways of life. As Nigeria battles the increasing rate of child labour and the attendant juvenile delinquency, it has become imperative that qualitative education should be made free, compulsory, relevant, attractive, and available for all, irrespective of their tribe, gender, religion, and geographical location. If child education is guaranteed, it, therefore, follows that parents would not see the need to give out their children as baby sitters and house helps to their relatives who initially promise to give the child good education whereas such relatives eventually use the innocent child in multiple labour such as domestic laundry and street hawking.
\end{abstract}

Keywords: Child labour, Crime, Delinquent Behaviour, Development, Drug trafficking, Juvenile, Poverty, Working Conditions, Socio-Economic, Stealing

\section{Introduction}

Child labour and delinquent behaviour are legal and socially constructed phenomenon, perceived globally as a social and human right abuse which has become an issue of great concern to global leaders, 
policy makers, scholars, and religious leaders across nations of the world, especially countries where the incidence is alarming (Fors, 2012; Ogunsakin, 2015). The definition of what constitutes child labour varies and is relative to time and place; it is determined by a country's cultural values, cultural norms, needs, and belief systems (Grier, 2004). According to International Labour Organisation (ILO) child labour can be seen as that kind of work which deprives children of the dignity of their potentials and this really hinders their physical and mental growth (ILO, 2004, p. 16; Hansungule, 2012). This explains why the concept of child labour is used in a denigrating and sneering sense. Osment and Jonsson (2014) note that the age of a child, the nature of work and the duration of time put into work are silent but important factors use in explaining whether a particular form of work can be classified as child labour. The act is particularly dangerous because it denies victims the opportunities to acquire the knowledge and skills necessary to liberate them from the poverty they were born or thrust into by circumstance (Ajake, Etuk \& Omori, 2010; Osment \& Jonsson, 2014; Ukwayi, J. K. \& Okpa, 2017).

Sharp, (1996); Orellana, (2001); Aufseeser, Bourdillon, Carothers, and Lecoufle, (2018); Pankhurst, Crivello, and Tiumelissan, (2015); Igbe, Okpa, and Aniah, (2017); Ipole, Agba, and Okpa, (2018); Peter and Okpa, (2019) made a distinction between child work and child labour. One common denominator in their explanation of what constitutes child work is that such activity does not compromise the physical, mental, social or educational development of children. The ILO recognizes that "activities such as doing chores around the home, assisting in a family business or earning pocket money outside school hours and during school holidays can contribute to children's development and provide them with skills and experience that prepare them to be productive members of the society during their adult life" (Diallo, Etienne, \& Mehran, 2013). However, The International Labour Organization Labour Act prohibits children from being employed to do any hazardous work (Dillon, Bardasi, Beegle \& Serneels, 2012). All the same, across the world's poorest countries, especially, across Africa and Asia, children in their millions watch helplessly to see their goals, hopes, and talents wrecked by child labour (Dillon, Bardasi, Beegle \& Serneels, 2012). On daily basis, their rights to knowledge, security, dignity, and a childhood free of exploitation are being steadily violated by caregivers, loved ones and significant others (Akinrimisi, 2002; Brown, 2011). According to Aufseeser, Bourdillon, Carothers, and Lecoufle, (2018) more than a quarter of children aged between 5-17 are engaged in life-threatening labour. In 2017, the International Labour Organisation (ILO) statistics has it that out of the 200 million child labourers, 120 million of these children are below the age of 10 years. It is also on record that subSaharan Africa has the highest prevalence rate of child labour in the world (ILO, 2017).

In a bid to protect the rights of the child, the Nigerian government in 2003 formulated Child's Right Act stipulating the minimum age for employment, yet, child labour and exploitation persists in rural and urban Nigeria given the underlying structures of poverty, inequality, social injustice, lack of decent work opportunities for adults, illiteracy, among other factors. Child labour has largely been blamed on the prevailing hostile economic conditions in the nation, leading to the engagement of under-aged children as significant partners in generating income to boost the economic well-being of the family (Ekpo \& Ajake, 2013; Fourchard, 2006).

Unfortunately, one of the resultant consequences has always been delinquent behaviour. Delinquent behaviour is linked to child labour and has become a common phenomenon in Nigeria (Gelles, 1993; Salawu, Alanamu \& Muhammed, 2011). Ugwuoke and Duruji (2015) posit that delinquent acts of examination malpractice, stealing, abuse of intoxicating beverages, burglary, pick pocketing, gambling, sexual improprieties, among others; is common among child labourers, many of whom have been apprehended and adjudicated in a juvenile court. This ugly trend has been blamed on the exposure of juveniles to commercial enterprises such as begging, manual labour, hawking, house helps, motor park touts, shoe shining bus conductors, and car washing (Okafor \& Bode-Okunade, 2003; Okafor \& Amayo, 2006; Tade, 2010; Taiwo, 2010). According to Bella, Atilola, and Omigbodun, (2010); Okpa, Ilupeju, and Eshiotse, (2020); Okpa \& Ukwayi, (2017); Ukwayi, Okpa, and Akwaji, (2019) delinquent acts are learnt and imbibed when working-class children make contact and interact with individuals exhibiting morally bankrupt life such like cultism, fraud, gambling, trafficking, armed robbery and arson, who often in the guise of patronizing their wares, indoctrinate and lure them into 
their nefarious lifestyles.).

Pressures from child labour reduce the ability of children to develop their potentials to full capacity, fulfil their life dreams and goals, these, in turn, put them under pressure, to exhibit delinquent lifestyles which are against the acceptable societal norms (Okpa \& Ekong, 2017; Adeniyi, Eneji, \& Okpa, 2019). Other causes of child labour as highlighted by Ugwuoke and Duruji, (2015); Ebingha, Eni, \& Okpa, (2019) are family disintegration, pervasive poverty, high rates of school dropouts, high level of industrialisation and rapid urbanisation, and poor implementation and enforcement of child protective social welfare services (example, being the non-implementation of the child rights law). Children who work as child labourers experience the ill effects of weariness, truancy at school, absentmindedness and lack of inspiration, inappropriate socialisation, susceptibility to sexual abuse, and a high tendency of exhibiting traits of juvenile delinquency (Dash, 2013).

Although, organisations across the globe are making tremendous attempts at curbing the activities instigating child labour and delinquent behaviour; with many nations adopting legislative measures prohibiting child labour and delinquent behaviour; nonetheless, child labour and delinquent behaviour are still widespread throughout the world and, particularly, in Nigeria (Asamu, 2015). Addressing the problem of child labour and juvenile delinquency will remain difficult or end in futility unless a broader approach that explores wholistic techniques in analysing the problem is adopted. A clear knowledge of the prevalence rate of child labour and its corelationship with juvenile delinquency can easily explain how pervasive these issues are to the larger society. Previous studies on child labour (Okafor, \& Bode-Okunade, 2004; Humert, 2009; Shailong, Onuk, \& Beshi, 2011; Sibiri, 2011; Sheikh \& Prodhan, 2013; Ugwuoke \& Duruyi, 2015; Nwazuoke, \& Igwe,2016; ) have fundamentally focused on the causes, nature, magnitude, effect, worst forms of child labour and legal procedure that could address the problem of child labour. Based on literature little is currently known on the relationship between child labour and delinquent behaviour in Nigeria. This paper through context analysis, a research tool used to determine the presence of certain words, themes, concepts or codifications within some given qualitative data (i.e. text) explores the nexus between child labour and delinquent behaviour in Nigeria, linking both social problems to existing socio-economic and cultural factors inherent in Nigeria social system. The paper analysed and interpreted both printed and electronic materials on child labour with the aim of eliciting data, gaining insight and developing empirical knowledge.

\section{Conceptualising Various Forms of Child Labour in Nigeria}

Domestic help: Domestic help, according to ILO (2013), refers to any person engaged in domestic work within an employable relationship. The term in day-to-day parlance refers to "House-help". In this context, it connotes a young child (usually aged between 5-15 years) living with a family, either related or not, engaged in performing several domestic chores, which includes baby-sitting, cooking, hawking, laundry, gardening, shopping, house cleaning, among others (Ibeme, 2014). The ILO Convention No. 189 classifies domestic workers as individuals contracted to sell their labour to third party private households (Ibeme, 2014; ILO, 2012). Domestic help performs an array of household services for families, which include the care for children and the elderly, household cleaning and maintenance (also referred to as housekeeping) (Awosusi \& Adebo, 2012). Children used as house-helps performs responsibilities such as household errands, laundry and ironing, cooking, foodstuff shopping, and others (Tade \& Aderinto, 2011; Awosusi \& Adebo, 2012).

Agricultural work: Many under-age working children are found in various farm settlements in rural and urban centres across the country (Nwokoro, 2011). They often work on family farms or are hired by extended family members or other members of the community to cultivate their farmlands.

Work in industries: In most commercial cities across Nigeria such as Lagos, Aba, Onitsha and Port Harcourt, under-age children are employed to work in most of the infant industries (Lanham, Lugalla, \& Mbwambo, 1996). These works include garment making, fireworks, chemicals, weaving, glassware, matches, gemstone polishing or other products, the work they carry out are either regular or casual. These imposed responsibilities expose juveniles to toxic chemical reactions such as 
poisoning, respiratory tract disease, skin infection, fire accident, collision, ear and eye damage, burns, cuts, and, even, death.

Prostitution and child trafficking: This is the worst form of child labour globally. This dimension of child labour is not only striking but poses imminent collateral damage to the health, integrity and personality of the child. Some of the dangers it poses to the child include: sexually transmitted diseases, moral bankruptcy, physical and psychological trauma and premature death (Nwazuoke and Igwe, 2016).

Work in the informal economic sector: This form of child labour is predominant in private enterprises which includes small and medium scale industries. Children are made to do odd jobs such as hawking waste and scrap gathering, waste sorting, newspaper vendor and begging such as in the Almajiri system (Omokhodion, Omokhodion, \& Odusote, 2005).

\section{Theoretical Framework}

\subsection{Blocked opportunity theory}

Attributed to Richard Cloward and Lloyd Ohlin (1960), the blocked opportunity theory supports Merton's idea that society's legitimate means of accomplishing our goals are not freely accessible to everyone. On the flipside of the coin, the same theory posits that access to illegitimate means of achievement of one's goals is not available to everyone in the society. In line with the postulation of this theory, factors such as poverty, frustration, and failure are perceived as being responsible for delinquent behaviour. This theory has been criticized based on the operational deficiency of the differential opportunity theory. Reid (1982) points out that the blocked opportunity theory shows a weak disposition when defining such concepts as "double failures" "perception of opportunity", "denial of legitimacy", "differential opportunity" and "elimination of guilt". Again, Schrage (1962) stresses the fallacy of alluding that high delinquency neighbourhoods are characterized by a particular type of subculture (Iwarimie-Jaja, 2012). Despite these criticisms, the assertions of this theory are noticeable in Nigeria. Delinquent behaviours occur in a situation where legitimate means of achieving cultural goals are blocked, and these are manifested in unpleasant consequences in society.

\subsection{Social bond theory}

Hirschi (1969) believes that bonds can either provoke good behaviour or bad behaviour. He argues that delinquency is the result of a weak or broken bond between the individual and society. In contrast, persons with a strong social bond are less likely to become delinquent. Therefore, the stronger the bond people have with society, the more effective their inner controls are, and the more they are unlikely to stray from the accepted rules and norms of the society (Iwarimie-Jaja, 2012). In his book "Causes of Delinquency", Hirschi asserts that "we are all animals and so we can commit crime" He then proposed that the stronger an individual's social bond is to social institutions (i.e, family, church, school), the lesser the likelihood that he will commit a crime (Hirschi 1969; Iwarimie-Jaja, 2012).

Hirschi identifies four major bonds, which are: attachment, commitment, involvement and belief. These elements to some extent will determine whether a person will be delinquent or not. But where these elements are inadequate, then delinquency becomes imminent. This theory has been criticized on the ground of its assumption that delinquency will occur if not prevented and that not all bond elements are the same. Another criticism of this theory is by Robert Agnew, a sociologist, who argues that Hirschi did not properly calculate the angles of the connection between criminality and a debilitated social bond.

Despite the criticisms identified, the theory is pertinent to the subject-matter under investigation. The contention of Hirschi (1969) is that people who have a weak bond with society are more likely to deviate from the accepted norms and values of that society. This applies to persons who are involved in delinquent behaviours because of child labour. Child labour can provoke disenchantment, 
frustration, sadness and hopelessness among juveniles. Consequently, resulting in the development of weak social bond, which makes victims of this social ills care less about others and demonstrate apathy towards socially approved ways of life. They may, therefore, engage in social activities; which society has proscribed as illegal but they consider it to be a lucrative means of livelihood and survival.

\section{Risk Factors Associated with Child Labour and Delinquent Behaviours in Nigeria}

The risk factors in this context are those characteristics or variables that, when present, contribute to making juveniles susceptible to certain lifestyles that can be detrimental to their well-being. Various factors contribute to the problem of child labour and delinquent behaviours in Nigeria. The issue of child labour and delinquent behaviour is one that is of major concern to different individuals, as various factors have been identified to facilitate this incidence in Nigeria. These factors include but not limited to; parents' financial status, cultural practices, parental illiteracy, broken homes and settlement of parents' debts, family size among others.

Parents' financial status: According to Bezuidenhout and Joubert (2008), families where parents have inadequate access to financial resources, experience some level of difficulty in providing the necessities of life for their family members. To address the problem of hunger and starvation within the family most juveniles engage in child labour and in the process indulge in delinquent behaviours like stealing and pick pocketing to meet their basic needs and provide for the family upkeep. In most cities in Nigeria, many unemployed or underemployed parents engage their children one form of child labour or the other to augment their financial and material deficiencies and so ameliorate or alleviate their poverty (Oketa, 2015). Consequently, Benatar (2008) postulates that delinquent behaviours occur at greater rates among economically disadvantaged young population. Thousands of children work in Nigerian's factories, dumpsites and industries as servants and scavengers under hazardous conditions, despite both Nigerian and international laws prohibiting hazardous child labour.

Cultural practices: In many indigenous communities across Nigeria, it has become an acceptable model for underage children to be involved in child labour; and this practice is justified under the guise of culture. Domestic and agricultural activities in Nigerian societies are culturally reserved for children as social instruments for child training and preparation for adulthood, however, some individuals use these cultures to deprive the child of his or her fundamental rights. Amin (1994) argues that in most rural areas in Nigeria, parents hide under the guise of culture to involve their children in child labour practices like agricultural activities and other domestic activities, such as house cleaning, cooking, fetching water and firewood from long distances, and carrying heavy loads. While, in the Nigerian urban centres, practices like domestic chores, child begging, street hawking and apprenticeship are the dominant forms of child labour supported by cultural practices. The perpetrators of these inhuman acts are often guardians, foster parents and outright employers of labour, who in the guise of cultural practises introduce elements of economic exploitation of the children in labour. Such children are vulnerable to delinquent behaviours such as truancy and abuse of alcoholic beverages to absconding from home, among others to consolidate on their new found illicit lifestyle.

Parental illiteracy: This is another social problem that has been promoting child labour in Nigeria. Kim and Zepeda (2004) reveal in their study that, while some families have preferences for their offspring to work based on the timeline, especially among those with average education in the rural agrarian societies, their counterparts with some relatively stable income in the urban areas opposed the notion. The study further notes that literate parents; their income notwithstanding, oppose child work because of the ills associated with the act. Chandra (200o) in his study singled out the educational level of parents as one of the key determinants of child labour. He maintains that education helps in conditioning the minds of parents regarding decisions to send their children or wards out to engage in child labour. Educated parents believe that children ought to be educated and nurtured to adulthood and should be allowed to decide the nature of labour they are willing to engage in. 
Broken homes: According to Ibeme (2014) broken homes occur when spouses divorce or separate from each other. Studies have shown that children raised in the absence of one parent leave an adverse effect in the child's psycho-social development, most times, such development is considered harrowing to the child's well-being. A child learns values and ethical behaviour from their nearest and dearest. This suggests that parents and significant others play an important role in nurturing a child into a responsible and respected adult. However, the crisis at home can make a juvenile develop violent disposition or show signs of juvenile delinquency. Broken homes have given rise to step-parenting system where a child is being raised by another parent. Most step-parents are indifferent or hostile to the children (usually not their children), while, paying better attention to their biological children, this can cause the neglected children to go astray or become violent. Children from these broken homes, being taken care of by their step-parents, could be subjected to worse forms of domestic work or separated from their remaining parent (Ibeme, 2014). Many who cannot bear the harsh treatment or face the psychological trauma of staying in their family home, prefer to runaway to cater for themselves.

There is a complex connection between parent's marriage complications, child labour and delinquent behaviour. Accordingly, there are a plethora of studies suggesting that broken homes are causal forces driving many juveniles into the streets to seek for safety and warmth. Thus, juveniles may become vulnerable to child labour and delinquent behaviour to secure food, shelter, and clothing for survival.

Settlement of parents' debt: Settlement of parents' debt refers to the repayment arrangement where an individual promise to offer services for the refund of debt, and there is no clear guideline of repayment. In many instances, the debts or wrong doings of parents are imposed on the children, therefore, using the children against their wills to settle parents' debt. Most of these children are sent off as domestic workers at home or farmlands, some serve as sex-slaves, and in some culture, these children are, even, killed to 'appease the gods' (ancestral deity). An instance in most underdeveloped societies is that most parents borrow money to develop their farmlands and use their children (one or more) as collateral; and where the debtor cannot repay the debt within the agreed period, the child will be subjected to bonded labour until the debt is paid (Quattri \& Watkins, 2016). These practices are rife in most Third world countries, and female children (mostly teenagers) are the worst hit being used as sex slaves, doing chores and in some cases working in the fields, with the male children engaging in manual/hard labours. This act exposes children to such delinquent behaviour as stealing, use of intoxicating beverages and fighting.

Family size: The size of a family has also been seen as contributing to the prevalence and entrenchment of child labour practices in Nigeria. Children from large-sized families are said to be more vulnerable to be engaged in child labour practices than those from small-sized families. Shailong, Onuk and Beshi (2011) in their study, show that most parents send their children to hawk wares and to supplement the family income and the income from the child hawker supports their mothers, mostly, in polygamous homes or a single-parent home. It can be inferred from the study, that child labour is more consistent in most polygamous and single parent homes. However, the study does not consider that some single parents and mothers in polygamous homes would rather do all the labour to promote the welfare of their children, without putting them through the risk associated with hawking.

\section{Child Labour and Delinquent Behaviour in Nigeria}

Child labour has become a fast-growing social phenomenon in Nigeria with its attendant consequences on moral standards that shape acceptable behavioural patterns among Nigerian children. The behavioural mal-adjustment associated with child labour according to Dantive and Haruna (2004) comprise issues such as insecurity, poor emotional reaction, and moral deformity. Child labour, particularly, hawking, scavenging, begging and collecting rubbish, exposes children to bad company, which negatively pressures them into delinquent behaviours such as, consumption of alcoholic beverages, stealing, truancy, disobedient to parental instruction, among others (Hughes, 2009; Humert, 2009; Humphrices, 2010). Besides, it exposes the children to all forms of anti-social behaviours 
and lifestyle that negatively distort their reasoning and make such a delinquent. The following delinquent behaviours have been identified to be linked directly to child labour in Nigeria:

Use of intoxicating beverages: The use of intoxicating beverages refers to the consumption of alcoholic beverages by juveniles (Lugalla, 1995; Lynch \& Scanlon, 2015). The general contention is that child labour creates a feeling of false maturity syndrome in the psyche of children, which stimulates them to think, behave and consume what they see adults consume including alcoholic beverages. Most children engaging in hawking gain knowledge of using drugs through interaction with people of questionable characters (Patience, Otu \& Ifeoma, 2015). Reports by UNDCP (1999); Femi (2015); Patience, Otu and Ifeoma, (2015) reveal that the use of intoxicating beverages among young people is alarming, especially, street children, orphans, and child commercial sex workers. The report shows that 8.2 per cent of young people ages 10-19 years have used marijuana. The report also shows a high incidence of self-medicated use of benzodiazepines, and other psychotropic substances, because of easy access. An earlier UNDCP (1999) study confirms the use of volatile organic solvents, such as gums and petrol, among street children, particularly, among Northerners in Nigeria.

Stealing: A child denied parental love and care suffers from depression, anger, isolation and consequently engages in stealing to survive. Ajake, Etuk, and Omori, (2010) report that three out of every ten criminals, apprehended in cities like Lagos, Ibadan, Kano, and Onitsha, are under 18 years. Furthermore, there is a new phenomenon of child labour, which has been attributed to street maintenance. These children pretend to fill bad spots on most major roads and often resort to begging. Beyond asking for alms, most of these juveniles go as far as partaking in highway robberies, by giving intelligence to older bandits or even device means to deflate or flatten supposed targets' vehicle tyres, trapping them down for easy looting. Most times, these children perpetuate the looting act by invading the window openings of trapped vehicles on bad roads or in traffic jams to raid passengers and even car owners of their belongings such as phones, monies, wristwatches, necklaces, and other valuable items catching their eyes (ACED, 2007; Nte, Eke \& Igbanibo, 2009). Juveniles, that work as bus conductors, engage in pick pocketing, snatching of handbags and indulge in gambling. Most robbery gangs operating in urban areas recruit young children as both informants providing information before an attack, and active foot soldiers trained to carry out their biddings in the future (Nte, 2005; Nte \& Ete, 2008).

Running away from home: Running away is characterized as the act of a young child unapproved disappearance from home for over 24 hours. Numerous runaway adolescents leave their homes to gain freedom and security from an abused treatment, be it physical or sexual abuse or even psychological abuse. This kind of abusive treatment is prominent among domestic-helpers (Onyejiaku, 1991). Among adolescents who run away from their supposed homes; many are either physically abused or sexually molested by their guardians or significant others. Of course, the consequences of this illtreatment/abuse on these children are devastating, and a leading cause of runaway cases reported overtime. Adolescents exposed to domestic violence overtime portray externalised and internalised behavioural problems; for example, externalised behavioural problems include - disobedience to parental demands and aggression, while internalised behavioural problems include physical protests, withdrawal syndrome, low self-confidence and tension. In this way, many domestic helps move out of their homes to get away from the viciousness. Other reasons include fear of getting consequences for an action such as being punished for misplacing money generated from sales of goods. Workload could also make a child run away from home. This workload includes constant washing and cleaning of the house, among other domestic chores.

School truancy: This entails voluntary and unauthorised absenteeism from school. The volume of work given to a child could make him or her stay away from school. This can be more severe when such a task has a fixed time for completion, with the threat of punishment, if not completed at the fixed time. This type of delinquent behaviour is common among domestic workers. Repeated running away from home to avoid punishment caused by a child's inability to finish the sale of goods, which he/she took to the market could make a child stay away from school. Also, the fear of punishment for misplacing money generated from the sales of goods could make a child stay away from home and 
school activities. This type of delinquent behaviour is common among hawkers. However, most of these children drop out from school to assist their parents in earning income for the family and can therefore, not combine making money and schooling (Ekpenyong \& Sibiri, 2011). Consequently, the practice of child labour is slightly modified in Eastern and Western Nigeria, children labour during the early hours of the day (from 6:00 am to 8:00 am) and after school hours. This, therefore, gives the children enough time to attend school and to earn money. More so, the school system is sometimes modified to accommodate morning and evening school attendees. Children who cannot attend morning schools because of their engagements are allowed to attend school in the evenings. However, from the free time they get outside school, they engage in money making ventures like trade learning, street hawking, and the likes to help boost and support their family income. Many parents in Northern, Nigeria engage their children in trading; this is to supposedly support household upkeep such as buying daily groceries. While some children, particularly, the girl child engage in trading to generate money to buy household goods to be given them when they marry, as early marriage is a common practise in Northern Nigeria (Oji, Ogwu \& Usifo, 2016).

Repeated disregard for or misuse of lawful parental authority. This refers to a pattern of repeated disobedience by the juvenile to the instructions of parents. Parental socio-economic status determines the level of respect they command within the family cycle (Ekpo \& Ajake, 2013). Many children exposed to child labour over time develop a feeling of false maturity syndrome; this affects their relationship with their parents, as they often do not take instructions from them. Many of these children hawk goods in disguise as a child labourer to augment the meagre income of their parents or guardians to eke out a living (Nte, Eke \& Igbanibo, 2009). The most distracting aspect of child labour is street hawking, it exposes children to delinquent behaviour as they make contact and interact with children exhibiting delinquent vices such as cultism, prostitution, drug addiction, human/drug trafficking, terrorism and arson. Through this contact and interaction, they learn to exhibit negative behaviours which make them utterly disregard parental instructions.

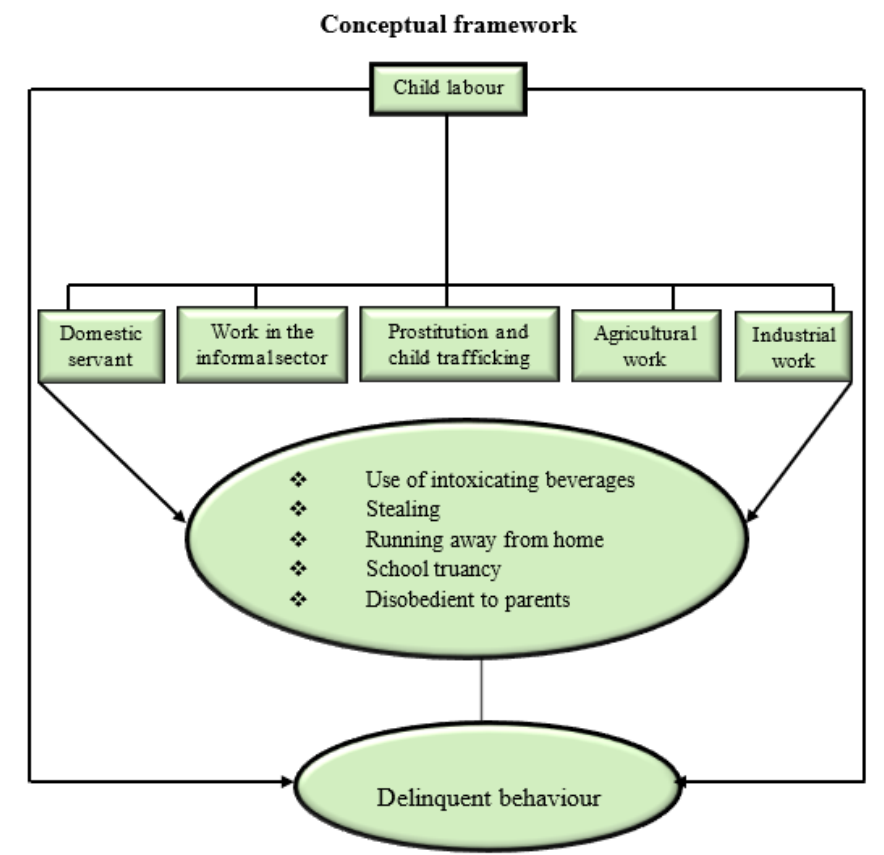

Figure 1. Diagram Explaining the Nexus Between Child Labour and Delinquent Behaviour Source: Child labour and delinquent behaviour by the author 
From this framework, the author contends that child labour is a contributing influence on the issue of delinquent behaviour in Nigeria. The author argues that children who are exposed to child labour of any sort, meet and interact with significant others who expose them to different forms of delinquent behaviour.

\section{Conclusion}

Life and work constitute a pair of universal phenomena, this explains why work attracts rewards. However, it is observed that the age factor is a critical issue - the difference between juvenile labour and legitimate labour is the age of the labourer. This is so because childhood is the formative period of any human being to go through all the needed processes of growth and develop into a complete adult and those processes include formal and qualitative education, sound moral upbringing and an appropriate and decent socialisation process. As its contribution to learning, this paper discovers that a child that is denied access to these time-bound processes of development will definitely exhibit some delinquent behaviours. When children are seen engaging in menial jobs such as hawking, begging, farm labour, scavenging for scraps, factory labour, it is an indication that they have missed the proper and necessary process of childhood development. Furthermore, this work explores that the false feeling of adulthood which the child experiences as a result of the adult labour he/she engages in, is a factor that contributes to juvenile delinquency. Also, constant association with people of questionable character helps the child exhibit delinquent behaviours.

\section{Suggestions for Policy Implementation}

Sequel to the findings of this paper, suggestions have been made to guide policy formulation. Although there are existing government policies on child labour, child labour remains a recurrent issue which suggests that there is an obvious policy gap which hinders the efforts of the government to address the issue of child labour. The findings of this paper would hopefully be useful in addressing the problem of abuse, delinquency and exploitation including child trafficking that is commonly associated with child labour in the society. In an ideal society, children are seen as the future generation and are provided with privileges and opportunities that foster their development and advancement in life. This brings to the fore the importance of education in addressing the problem of child labour and juvenile delinquency in Nigeria. Education is a proven strategy for reducing child labour and delinquent behaviour. Lack of access to education leaves an increasing cycle of poverty, illiteracy, exploitation, limiting future career aspirations, and makes for the acceptance of low-wages by children as against what is earned by adults in the same work, leading to a vicious cycle of poverty as the children grow and start their own families. Thus, having access to education at a young age can help break the jinx/pattern of poverty from its root, while, reducing child labour and delinquent behaviour. Government at all levels in Nigeria should demonstrate strong political will and commitment in addressing the rot in the educational system by proper and adequate funding, improved public school facilities, and effective monitoring mechanism including better remuneration for extremely low paid teachers.

Nigeria frowns at child labour and has made it illegal through her grand norms and various legislations aimed at protecting the rights of children. The Nigeria Constitution also protects the rights of children by making primary education a Fundamental Right. Unfortunately, at present, child labour exists in many indiscernible forms. Across Nigeria, millions of child labour cases are perpetrated daily and yet those who should address the problem feign ignorance and turn a blind eye to the matter. Based on this show of apathy, offenders now have a field day exploiting innocent children as hawkers, cooks, dry cleaners and general house keepers. Failure to speak up and take serious action against child labour is another way of promoting crime. By implication, these silent on-lookers see children as utilities and beast of burden who are readily available for any taskmaster who needs their services. This error will lead to distorted labour practise whereby dependable and energetic men and women are 
gradually edged out of the workforce and replaced by cheap child labourers who are engaged on a hire and fire basis. This development can doom the economic development of a nation, and attract the wrath of global patterns considering the resolve and commitment by the United Nations to bring an end to these inhuman practices. Against this background anybody found guilty of violating the rights of children in this regard should be severely made to face the full wrath of the law.

Despite the advances in Nigeria's child labour act, child labour is still widespread in the country. This has made some schools of thought to argue that since work is beneficial to children's mental and health development, instead of prohibiting children from working, governments should rather develop a robust legal framework that ensures that children enjoy the same labour, rights and protections as their adult counterparts in the workplace. This school of thought believe that children should not be engaged in economic activities that are harmful, dangerous, or which interfere with their well-being and development. The engagement of children should be limited to assisting their parents, guardians or neighbours at home, supporting their parents after school or during a holiday in running the family business as well as other sundry responsibilities that do not affect the child's development. These kinds of economic engagement are healthy to the child's development as they provide them with knowledge and skills that prepare them to be productive adults in the future. Nonetheless, the labour situation in Nigeria calls for subtle strategies that guarantee the protection of children's rights, concerns and interests. This is of particular interest because children are helpless and vulnerable, hence it has become imperative to strengthen laws aimed at protecting them from exploitation and victimisation.

\section{References}

Adeniyi, E. K., Eneji, R. I. \& Okpa, J. T. (2019). Unemployment and drug trafficking among suspects in custody of the National Drug Law Enforcement Agency, Cross River State command, Nigeria. European Scientific Journal 15, 191-202

Ajake, U. E., Etuk, G. R. \& Omori, A. E. (2010). Child rearing style and brutal behaviour among senior secondary school students in Cross River State. Journal of Counselling Association of Nigeria. CALJOCAN, 4(4), $162-167$.

Akinrimisi, A. (2002). Empowerment of young persons-in-non-formal sector: The case of female adolescent domestic workers in Municipal Lagos. Online available at: www.cewhin.orgAppreciating\%2othe\%2oPlight $\% 200 \%$ 2oDomestic\%2oWorkers.doc

Amin, A. A. (1994). The socioeconomic impact of child labour in Cameroon. Labour Cap Soc., 27(2): $234-49$.

Asamu, F. F. (2015). Child labour and its social implications on children in selected cities in Nigeria. Global Journal of Arts, Humanities and Social Sciences, 3, 2, 62-74.

Aufseeser, D., Bourdillon, M., Carothers, R., \& Lecoufle, O. (2018). Children's work and children's well-being: Implications for policy. Dev Policy Rev. 36: 241-261.

Awosusi, O. \& Adebo, G. M. (2012). Domestic servants and rural-youth urban migration in Nigeria: Issues for National intervention. International Journal of Humanities and Social Science, 2 (5), 271-278.

Bella, T. T., Atilola, O. \& Omigbodun, O. O. (2010). Children within the juvenile justice system in Nigeria. Psychopathology and psychosocial needs. Annals of Ibadan Post-Graduate Medicine, 8(1), 34-39.

Benatar, S. (2008). From Promiscuous to Prim: Gaining Better Understanding of Adolescent Sexual Risk Taking Using the National Longitudinal Study of Adolescent Health.

Bezuidenhout, C., \& Joubert, S. (2008). Child and youth misbehaviour in South Africa (2nd edition). Van Schaik Publishers: Pretoria.

Brown, G. (2011). Child labour E educational disadvantage, breaking the link, building opportunity. David Parker.

Chandra, P. (200o). Child labour: perception of the parents. A case study of Govandi area, Mumbai, India (Abstract). International Institute for Population Sciences, 14. Retrieved from Science Direct database.

Cloward. R. A. \& Ohlin, L. (1960). Delinquency and opportunity: A theory of delinquent gangs. New York: Free Press.

Dash, B. M. (2013). Factors contributing in the incidence of child labour in small scale commercial establishments: A study in Delhi. OIDA International Journal of Sustainable Development, 5, 12, 41-58.

Diallo, Y., Etienne, A. \& Mehran, F. (2013). Global child labour trends 2008 to 2012. International Labour Office, International Programme on the Elimination of Child Labour (IPEC) - Geneva: ILO.

Dillon, A., Bardasi, E., Beegle, K., \& Serneels, P. (2012). Explaining variation in child labor statistics. Journal of Development Economics, 98(1), 136-147. 
Ebingha, E. E., Eni, J. S., \& Okpa, J.T. (2019). Population growth and socio-economic development of Cross River State, Nigeria. European Journal of Economic and Financial Research 3(3), 20-35

Ekpo, E. T. \& Ajake, U. E. (2013). Family socio-economic status and delinquency among senior secondary school students in Calabar south, Cross River State, Nigeria. American International Journal of Contemporary Research, 3(4), 83-88.

Femi, A. F. (2015). Child labour and its social implications on children in selected cities in Nigeria. Global Journal of Art Humanities and Social Sciences, 3(2), 62-74.

Fors, H. (2012). Child labour: A review of recent theory and evidence with policy implications. Journal of Economic Surveys, 26(4), 570-593.

Fourchard, L. (2006). Lagos and the Invention of Juvenile Delinquency in Nigeria 1920 - 60.

Gelles, R. (1993). Family reunification/family preservation: are children really being protected, Journal of Interpersonal Violence, 8, 557-563.

Grier, B. (2004). Child labor and Africanist scholarship: A critical overview. African Studies Review, $47(2), 1-25$.

Hansungule, M. (2012). The African charter on human and peoples' rights. In A.A. Yusuf \& F. Ouguergouz (Eds.), The African Union: Legal and institutional framework. A manual on the Pan-African Organization (pp. 417 453). Leiden: Koninklijke Brill NV.

Hirschi, T. (1969). Causes of delinquency. Berkeley: University of California Press.

Hughes, S. D. (2009). Child abuse spikes during recession. CNB News. In Ekpenyong, S. \& Sibiri, A. (2011). Street Trading and Child Labour in Yenegoa. International Journal of Scientific Research in Education, 4.1, 36-46.

Humert, F. (2009). The challenge of child labour in international law proposals. Human Rights Quarterly, $3(1) 46$.

Humphrices, J. (2010). Childhood \& child labour in the British industrial revolutions.

Ibeme, N. P. (2014). Child domestic worker in rural and urban areas in Nigeria: Implications for national development. International Journal of Emerging Knowledge, 1(12), 219-231.

Igbe, J. E., Okpa, J. T., \& Aniah, E. A. (2017). Working conditions and deviant behaviour of employees in the University of Calabar, Cross River State, Nigeria. IOSR Journal of Humanities And Social Science (IOSR-JHSS). 22(7),74-83

Igbo, E. U. M. (2007). Introduction to criminology. Nsukka: Afro-Orbis Publication Ltd.

ILO (2012) Combating Trafficking in Children for Labour Exploitation in West and Central Africa. The International Programme on Elimination of Child Labour (IPEC) International Labour Office, ILO, Geneva. ILO (2003).

ILO (2013). A future without Child Labour Global Report under the follow-up to the ILO Declaration on fundamental principles and right at work, 2002.

ILO (2016) Child labour in Africa, Manual (General 2019).

International Labour Office (ILO) (2017). Global estimates of child labour: Results and trends, 2012-2016. Geneva

International Labour Organization. (2004). Child labour: A text book for university students. International Labour Office. Geneva: Author

Ipole, P. A., Agba, A. O., Okpa, J. T. (2018). Existing working conditions and labour unions agitations in Cross River state civil service, Nigeria. Global Journal of Social Sciences Studies 4 (1), 39-51

Iwarimie-Jaja D. (2012). Criminology: The study of crime. 4 th edition. Owerri; Spring-field publisher ltd.

Kim, J. \& Zepeda, L. (2004). Factors affecting children's participation and amount of labor on family farms. Journal of Safety Research, 3(4):391-401.

Lanham, M. D., Lugalla, J. \& Mbwambo, J. (1996). "Street children and street life in urban Tanzania: The culture of sorrowing and its implications on children's health", Unpublished Research Report.

Lugalla, J. (1995). Crisis, urbanization and urban poverty in Tanzania: A study of urban poverty and survival politics. University Press of America.

Lynch, M. \& Scanlon, F. (2015). Child labour. BMJ, 325, 401-403.

Nte, N. D. \& Eke P. (2008) Youth Secret Cults and Political Violence in Rivers State: A Review of the 4th Republic", Bangladesh e-Journal of Sociology, 6(2),

Nte, N. D. (2005). The political economy of child labour in a depressed economy: The case of Port Harcourt City, Nigeria”. In Ifeanacho, M. (ed) The Socio-Anthropological Perspective of African Development crisis. A Publication of the Department of Sociology, Faculty of Social Sciences, University of Port Harcourt, Nigeria.

Nte, N. D., Eke, P. \& Igbanibo, S. T. (2009). Street children and the challenges of national security: evidence from Nigeria. Bangladesh e-Journal of Sociology, 6 (2), 28-37.

Nwazuoke, A. N. \& Igwe, C. U. (2016). Worst forms of child labour in Nigeria: An appraisal. International and Local Legal Regimes. Beijing Law Review, 7, 69-82.

Nwokoro, C. N. (2011). The challenge of child labour to the achievement of MDG2: case study of South-East Nigeria. A Master's Thesis in Human Development and Food Security, Department of Economics, Universita' Degli studi Roma Tre.

Ogunsakin, J. (2015). A legal prognosis of child labour under the Nigeria child's right acts. International Affairs and Global Strategy, 30, 28-36. 
Oji, J., Ogwu, D. A. \& Usifo, E. C. (2016). Hawking and its effect on child's education: A case study of children of Port Harcourt, River state, Nigeria. Academic Scholarship Journal, 12(1), 149-16o.

Okafor, E. E. \& Amayo, O. E. (2006). Parents and their coping strategies in Nigeria: A study of selected working mothers. International Journal of Sociology of the Family 32, 87-111.

Okafor, E. E. \& Bode-Okunade, A. S. (2004). Institutional collapse and child labour: The pervasive problem of street hawking in Nigeria. In V. T. Jike (Ed.). The scourge of child labour in Nigeria: A book of reading (pp. 90-102). Lagos, Nigeria: NIS.

Oketa, C. M. (2015). Culture and child labour practices in Ebonyi State Nigeria. Multi-Disciplinary Journal of Research and Development Perspective 4 (2), 29-42.

Okpa, J. T. \& Ekong, I. D. (2017). Global and national terrorism: implications for sustainable development in Nigeria. IOSR Journal of Humanities And Social Science (IOSR-JHSS) 22 (11), 49-56

Okpa, J. T. \& Ukwayi, J. K. (2017). Drug suspects perception of factors responsible for illicit drug trade in Cross River State, Nigeria. IOSR Journal of Humanities and Social Science (IOSR-JHSS) 22 (5), 80-87

Okpa, J. T., Ilupeju, A. A. \& Eshiotse, E. (2020). Cybercrime and socio-economic development of corporate organisations in Cross River State, Nigeria.. Asian Journal of Scientific research 13 205-213

Omokhodion, F. O., Omokhodion, S. I. \& Odusote, T. O. (2005). Perceptions of child labour among working children in Ibadan, Nigeria. Child Care, Health \& Development, 32(3), 281-286.

Onyejiaku, F. O. (1991). Psychology of adolescence. Calabar: Rapid Educational Publishers.

Orellana, M. F. (2001). The work kids do: Mexican and Central American immigrant children's contributions to households and schools in California. Harvard Educational Review, 71, 366-389.

Osment, L. \& Jonsson, E. (2014). Child labour: The effect on child, causes and remedies to the revolving menace. A thesis work submitted to the Department of Human Geography, University of Lund, Sweden.

Pankhurst, A., Crivello, G., \& Tiumelissan, A. (2015). Work in children's lives in Ethiopia: Examples from Young Lives communities. In A. Pankhurst, M. Bourdillon, \& G. Crivello (Eds.), Children's work and labour in East Africa: Social context and implications for policy (pp. 41-74). Addis Ababa: OSSREA.

Patience, B. I., Otu, O. O. \& Ifeoma, O. M. (2015). Influence of street hawking on socio-emotional development of children: A case study of primary school pupils in Cross River State, Nigeria. Journal of Emerging Trends in Educational Research and Policy Studies, 6(1), 50-55.

Quattri, M. \& Watkins, K. (2016). Child labour and education: A survey of slum settlements in Dhaka. London overseas development institute.

Reid, S. T. (1982). Crime and criminology, $3^{\text {rd }}$ edition. New York: Holt, Remehart and Winston/CBS College publishing.

Salawu, A., Alanamu, A. S. \& Muhammed, A. Y. (2011). The nexus between family instability and youth Journal of African History, 47: 115-37.

Schrage, C. (1962). Delinquency and opportunity: Analysis of a theory. In Voss, Society. Delinquency and delinquent behaviour.

Shailong, C. N., Onuk, E. G. \& Beshi, B. A. (2011). Socio-economic factors affecting children hawkers in Lafia Local Government Area, Nasarawa State, Nigeria. Patnsuk Journal, 7, 1, 64-73.

Sharp, L. A. (1996). The work ideology of Malagasy children: Schooling and survival in urban Madascar. Anthropology of Work Review, 17, 36-42.

Sheikh, M. R. \& Prodhan, M. (2013). The socio-economic deprivation of the child labourer: Bangladesh perspective. Journal of International Social Issues 2(1), 45-59

Tade, O. \& Aderinto, A. A. (2011). Socio-demographic predictors of domestic outsourcing among working women in Ibadan, Nigeria. Pakistan Journal of Social Sciences 8(4), 198-204.

Tade, O. (2010). Household Demand and Child Trafficking for Domestic Use in Ibadan, Nigeria. A Ph.D. post-field Seminar presented at the Department of Sociology, University of Ibadan, Nigeria.

Taiwo, I. (2010). Toyota Bus Stop: Gridlock without end. The Guardian, March 23.

Ugwuoke, C. U. \& Duruyi, O. U. (2015). Family instability and juvenile delinquency in Nigeria: A study of Owerri Municipality. IOSR Journal of Humanities and Social Sciences, 20 (1), 40-45.

Ugwuoke, C. U. (2010). Criminology: Explaining crime in the Nigerian context. Nsukka: Great Ap Express Publishers Ltd.

Ukwayi, J. K. \& Okpa, J. T. (2017). The Effect of Electoral and Economic Crimes on Sustainable Development in Cross River State, Nigeria. International Journal of Social Science Research 5 (2), 32-42

Ukwayi, J. K., Okpa, J. T., \& Akwaji, F. (2019). Trends in illicit drug trafficking in Nigeria: highlighting the imperative of raising the red flag. American journal of social sciences and humanities 4 (1), 25-37

UNDCP (1999) Report of the rapid situation assessment of drug abuse in Nigeria. United Nations International Drug Control Programme, Nigeria 